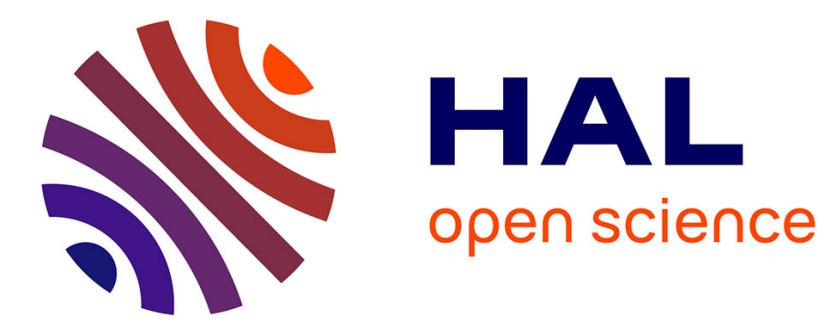

\title{
Fireside corrosion on T24 steel pipes and HVOF NiCr coatings exposed to different salt mixtures
}

N Abu-Warda*, A.J. López, F. Pedraza, M.V. V Utrilla

\section{To cite this version:}

N Abu-Warda*, A.J. López, F. Pedraza, M.V. V Utrilla. Fireside corrosion on T24 steel pipes and HVOF NiCr coatings exposed to different salt mixtures. Corrosion Science, 2020, 173, pp.108747. 10.1016/j.corsci.2020.108747 . hal-02660027

\section{HAL Id: hal-02660027 https://hal.science/hal-02660027}

Submitted on 30 May 2020

HAL is a multi-disciplinary open access archive for the deposit and dissemination of scientific research documents, whether they are published or not. The documents may come from teaching and research institutions in France or abroad, or from public or private research centers.
L'archive ouverte pluridisciplinaire HAL, est destinée au dépôt et à la diffusion de documents scientifiques de niveau recherche, publiés ou non, émanant des établissements d'enseignement et de recherche français ou étrangers, des laboratoires publics ou privés. 


\title{
Fireside corrosion on $\mathrm{T} 24$ steel pipes and HVOF NiCr coatings exposed to different salt mixtures
}

\author{
N. Abu-warda*1, A.J. López ${ }^{1}$, F. Pedraza ${ }^{2}$, M.V. Utrilla ${ }^{1}$ \\ ${ }^{1}$ Dpto. de Matemática Aplicada, Ciencia e Ingeniería de Materiales y Tecnología Electrónica \\ (ESCET), Universidad Rey Juan Carlos, Tulipán s/n, 28933 Móstoles, Madrid, Spain. \\ ${ }^{2}$ Laboratoire des Sciences de l'Ingénieur pour l'Environnement - Université de La Rochelle \\ (LaSIE, UMR-CNRS 7356), Avenue Michel Crépeau, 17042 La Rochelle Cedex 1, France. \\ *Corresponding author: Tel. +0034914887160 E-mail: najib.abuwarda@urjc.es (Najib)
}

\begin{abstract}
Fireside corrosion of T24 steel and HVOF NiCr-coated counterparts is investigated. The samples were exposed to different deposits of $\mathrm{NaCl}, \mathrm{KCl}, \mathrm{Na}_{2} \mathrm{SO}_{4}$ and $\mathrm{K}_{2} \mathrm{SO}_{4}$ at $650{ }^{\circ} \mathrm{C}$ for $360 \mathrm{~h}$ in dry air. The deposit with the highest chloride content $(\mathrm{NaCl}-\mathrm{KCl})$ was the most aggressive followed by the ones combining chlorides and sulfates. In contrast, the sulfate-based salts did not produce severe damage. The NiCr coating maintained the integrity of the substrate but the chlorides induced a great attack on the coating. The formation of $\mathrm{K}_{2} \mathrm{CrO}_{4}$ and the penetration of chlorides are identified as the main factors of this attack.
\end{abstract}

Keywords: A. Metal coatings; A. Steel; B. SEM; B. XRD; C. High temperature corrosion; C. Hot corrosion

\section{INTRODUCTION}

Global warming is leading the energy industry to reduce greenhouse gas emissions. In fact, $41 \%$ of worldwide $\mathrm{CO}_{2}$ emissions are derived from electricity and heat production [1]. For this reason, the replacement of conventional fossil fuels by renewable sources 
including biomass is continuously growing. Biomass is considered carbon-neutral and it is expected that its use will take the lead over pulverized coal-fired power plants [2]. Cofiring low amounts of biomass has proved to be a successful way to introduce carbonneutral fuels. Further reductions in $\mathrm{CO}_{2}$ emissions can be achieved increasing the efficiency of co-firing power plants by working at higher temperatures and pressures. Conventional power generation plants operate at an efficiency of $36 \%$, however, an increase of $1 \%$ in the efficiency can produce a reduction of $3 \%$ in $\mathrm{CO}_{2}$ emissions [3]. Therefore, it is expected that working temperatures will be in excess of $650{ }^{\circ} \mathrm{C}$ and the presence of biomass in co-firing power plants will be increased [4]. One of the most limiting factors in increasing the efficiency of power plants is the availability of materials to withstand these aggressive conditions [5]. This would require the substitution of conventional ferritic steels used so far by more expensive materials, such as Ni-base alloys, whose price can be up to 10 times higher [6].

In the particular case of biomass in co-firing power plants, the surface of the materials can be exposed to different salts deposits of various compositions. The continuous change in the deposit chemistry can modify the corrosion mechanisms $[7,8]$. Therefore, the boiler environments become more aggressive than using only coal as fuel. For heat exchanger pipes, fireside corrosion can be a critical life-limiting factor. Metal-loss due to chemical reactions can lead to pipe failure through metal-loss itself or cracks formation. The extent of the attack by fireside corrosion mainly depends on the exposure temperatures and the composition of the deposits.

An alternative to reduce material costs is the use of $\mathrm{Ni}$-based alloys as protective coatings on conventional ferritic steel substrates [9]. In this context, Ni-based coatings could be just as effective as bulk Ni-based alloys as long as the coating is dense, compact and completely adhered to the substrate. The use of advanced deposition techniques such as 
high velocity oxy-fuel (HVOF) becomes essential to obtain these coating properties. This technique also provides low porosity and a high degree of compaction of the metallic powders due to the high spraying velocities [10]. Moreover, the low exposure time of the metallic powders to flame produces coatings with a low oxide content. This prevents the presence of cracks and defects and facilitates the anchoring of the particles to the substrate $[11,12]$.

Despite the growing number of works on fireside corrosion in biomass-like environments as those of Uusitalo et al. [13-15], who pioneered the studies on active chlorine corrosion in HVOF coatings in chlorine containing environments, the role of the salts on the degradation mechanisms is not fully understood. Li et al. [16] investigated the hot corrosion behavior of different $\mathrm{Fe}-\mathrm{Cr}$ rich alloys with $\mathrm{NaCl}-\mathrm{KCl}$ deposits and found a great reactivity of $\mathrm{Cr}$ and $\mathrm{Cr}_{2} \mathrm{O}_{3}$ with the chlorides. They also found that the corrosion trend was very similar to the behavior caused by individual $\mathrm{KCl}$ or $\mathrm{NaCl}$. However, their tests were performed for just $48 \mathrm{~h}$, which often corresponds to the onset of corrosion. Sarvghad et al. [17] demonstrated that the most vulnerable steels are those with the lowest $\mathrm{Cr}$ content when exposed to molten $\mathrm{NaCl}-\mathrm{Na}_{2} \mathrm{SO}_{4}$ at $700{ }^{\circ} \mathrm{C}$. Mlonka-Medrala et al. [18] conducted a thorough study where the effect of the composition of the salts deposited on a low-alloyed steel was analyzed. They found that pure $\mathrm{KCl}$ was the most aggressive salt at $550{ }^{\circ} \mathrm{C}$ but the eutectic $\mathrm{KCl}-\mathrm{K}_{2} \mathrm{SO}_{4}$ mixture was the most aggressive at $600{ }^{\circ} \mathrm{C}$. The authors associated this behavior to the melting point of the ash $\left(774\right.$ and $694{ }^{\circ} \mathrm{C}$ for pure $\mathrm{KCl}$ and eutectic $\mathrm{KCl}-\mathrm{K}_{2} \mathrm{SO}_{4}$ mixture, respectively). However, our work intends to shed light on the degradation mechanisms of both a low alloyed T24 steel and a HVOF Ni20Cr coating as a function of salt composition at $650^{\circ} \mathrm{C}$ to accelerate degradation. The salt mixtures based on $\mathrm{NaCl}, \mathrm{KCl}, \mathrm{Na}_{2} \mathrm{SO}_{4}$ and $\mathrm{K}_{2} \mathrm{SO}_{4}$ have been selected according to their eutectic point and because were used as standard deposits employed in the studies 
described above [16-18]. Metal damage of each substrate-coating-deposit system is quantified by gravimetric measurements and dimensional metrology and the corrosion mechanisms are elucidated with the advent of SEM/EDX and XRD techniques.

\section{EXPERIMENTAL PROCEDURE}

\subsection{Materials}

Ferritic-martensitic ASTM-SA213-T24 steel pipes (manufactured by Vallourec Co) of 7 $\mathrm{mm}$ thickness and $44 \mathrm{~mm}$ external diameter were employed as substrate material. The external surface of steel pipes was sandblasted with $1 \mathrm{~mm}$ diameter alumina particles to increase surface roughness before the deposition of the Ni20Cr alloy coating by HVOF technique. The optimization of HVOF thermal spray process was performed in a previous study [19].

\subsection{Exposure conditions}

The uncoated and the coated steel pipes were cut into segments of approximately $5 \mathrm{~mm}$ long, and with a $30 \mathrm{~mm}$ and $20 \mathrm{~mm}$ exterior and interior chord, respectively. These samples were subjected to high temperature corrosion test at $650^{\circ} \mathrm{C}$ in a Nabertherm LT 5/12/P330 furnace in air atmosphere for $360 \mathrm{~h}$ following the standard ISO/FDIS 17224:2014 for high temperature corrosion tests [20]. Four salt mixtures were deposited to simulate different fireside corrosion environments in the heat exchanger tubes employed in co-fired power plants. The composition of each salt mixture is shown in Table 1. The condition S0 (Salt 0 ) refers to the isothermal test without any deposit and these S0 samples were used as reference. The composition of the S1, S2 and S3 salts was selected according to their relatively low eutectic point. Further, the S4 salt mixture was selected for being a standard deposit widely employed for screening tests in fireside 
corrosion to represent the composition of alkali-iron tri-sulfate [21]. $\mathrm{No} \mathrm{SO}_{2} / \mathrm{SO}_{3}$ was added to the system to underline the effect of the salts solely.

The samples were covered with the different salt mixtures and they were placed in alumina crucibles before thermal testing. The deposit-recoat test method was used and samples were recoated $\left(\sim 15 \mathrm{mg} / \mathrm{cm}^{2}\right)$ every $90 \mathrm{~h}$ until $360 \mathrm{~h}$. This method has been used extensively by other authors $[22,23]$.

Table 1 Salt mixtures nomenclature, composition of deposits used in fireside corrosion tests (mol \%) and theoretical melting temperatures $\left({ }^{\circ} \mathrm{C}\right)$.

\begin{tabular}{ccccccc}
\hline $\begin{array}{c}\text { Salt mixture } \\
\text { nomenclature }\end{array}$ & $\mathbf{N a C l}$ & $\mathbf{K C l}$ & $\mathbf{N a}_{2} \mathrm{SO}_{4}$ & $\mathbf{K}_{2} \mathbf{S O}_{4}$ & $\mathbf{F e}_{2} \mathbf{O}_{3}$ & $\mathbf{T}_{\mathbf{m}}\left({ }^{\circ} \mathbf{C}\right)$ \\
\hline S0 & - & - & - & - & - & - \\
\hline S1 & 50.6 & 49.4 & - & - & - & 657 \\
\hline S2 & 53.3 & - & 46.7 & - & - & 626 \\
\hline S3 & - & 74 & - & 26 & - & 690 \\
\hline S4 & - & - & 37.5 & 37.5 & 25 & $>650$ \\
\hline
\end{tabular}

\subsection{Damage analysis}

The damage produced by the deposits on T24 steel samples was analyzed by gravimetric tests (evolution of the mass change every $90 \mathrm{~h}$ ) and dimensional metrology (measuring metal loss). The first method allows us to compare the effect of each deposit with time and it gives a very good indication of oxide delamination. However, this method is not useful for the coated samples because only the external surface was coated. For this reason, dimensional metrology was also employed to quantify metal damage in terms of metal loss distribution. This method has been extensively employed by other authors because it provides a good quantification of the corrosion rate [22]. To perform this analysis, one hundred measurements of samples thickness were done at equidistant distances before and after thermal test. In this manner, the entire cross-section of the sample was assessed. The difference between the initial and final thickness was 
considered as metal loss. These measurements were done on cross-section micrographs of the samples using LAS.V4 Leica image analysis software.

\subsection{Samples characterization}

The microstructural analysis of the cross-sectioned samples was performed before and after high temperature test. These samples were cold-mounted and polished using waterfree lubricants and suspensions to avoid the removal of water-soluble salts and corrosion products. The analyses were performed employing a Leica/DMR optical microscope (OM) and a Hitachi S3400N SEM. Semi-quantitative compositional analysis were also carried out using the X-ray dispersive energy (EDX) technique with a Bruker XFlash 5010 detector.

X-ray diffraction (XRD) was also employed to characterize the reaction products presented in samples surface after the corrosion tests. A Panalytical X'Pert PRO diffractometer was employed using monochromatic $\mathrm{K}_{\alpha \mathrm{Cu}}(1.54056 \AA)$ as the radiation source with $45 \mathrm{kV}$ and $40 \mathrm{~mA}$. The diffraction patterns were recorded in an angular interval of $20-90^{\circ}$, with the step of $\Delta(2 \theta)=0.04^{\circ}$ and time per step of $1 \mathrm{~s}$.

\section{RESULTS}

\subsection{Characterization of the starting materials}

Fig. 1 shows a cross-section of the HVOF Ni20Cr coating on a T24 ferritic-martensitic steel. Their full characterization was previously reported in [19]. In essence, the steel has a ferritic-martensitic microstructure with an average grain size of $14 \mu \mathrm{m}$ while the coating is homogeneous, well adhered to the substrate (29 $\pm 7 \mathrm{MPa})$ and fully dense with very low porosity ( $<1 \mathrm{vol} \%)$ and high micro-hardness $\left(460 \pm 30 \mathrm{HV}_{0.1}\right)$. In addition, it shows a low oxide content $(4 \pm 1 \mathrm{vol} \%)$ and presents an average minimum thickness of $260 \pm$ $20 \mu \mathrm{m}[19]$. 


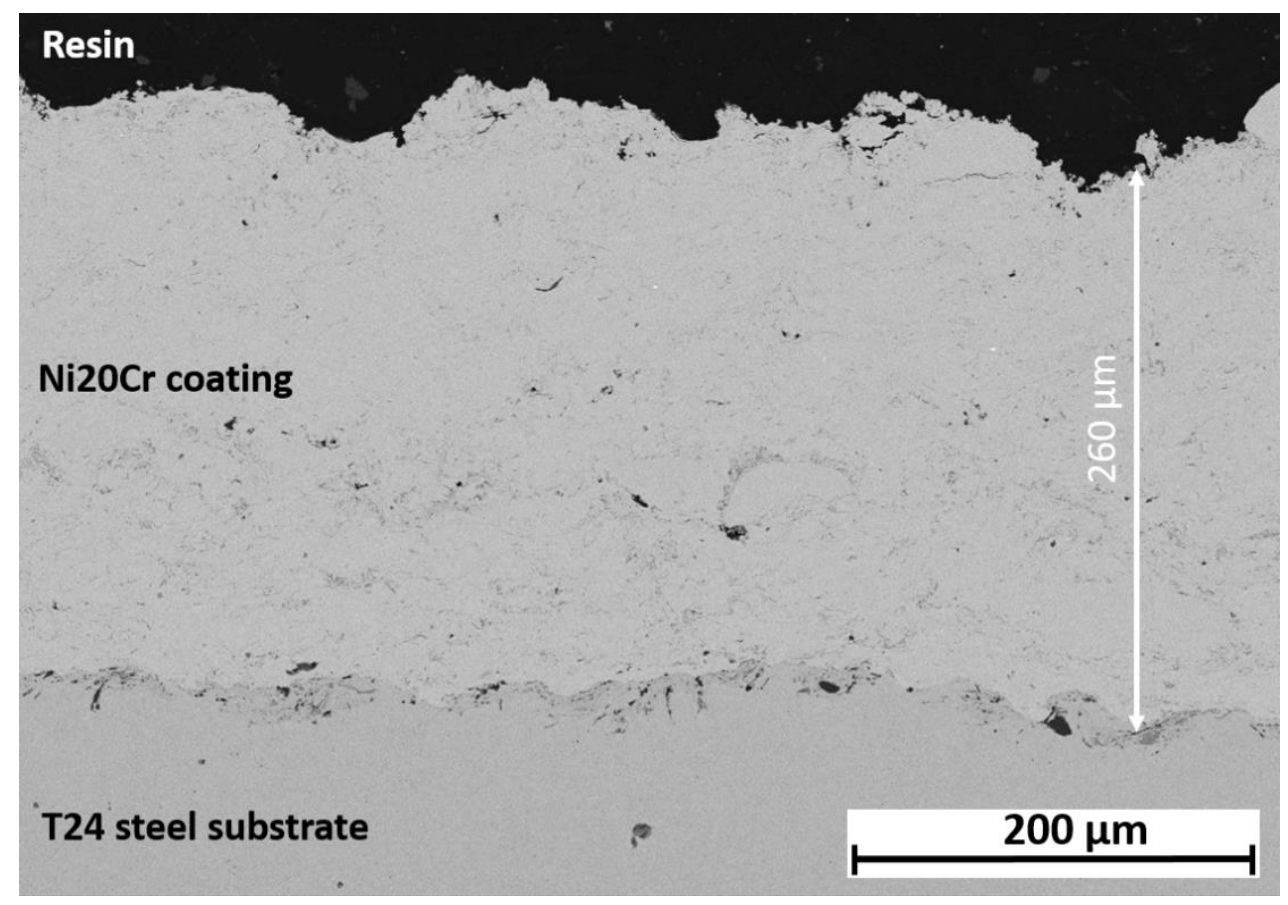

Fig 1 Cross-section micrograph of HVOF Ni20Cr coating on T24 steel [19].

\subsection{Measurement of metal damage}

\subsubsection{Thermogravimetric analysis}

Fig. 2(a) shows the mass gain of T24 steel substrate after $360 \mathrm{~h}$ of exposure to different salt mixtures. The mass gain increases markedly during the first $90 \mathrm{~h}$ and then tends to slow down. One can also observe significant differences as a function of the composition of the salt. Based on the trend of Fig. 2(a), the aggressiveness of the different salt mixtures in $\mathrm{T} 24$ steel would follow the sequence $\mathrm{S} 0 \approx \mathrm{S} 4<\mathrm{S} 2 \approx \mathrm{S} 3<\mathrm{S} 1$. This clearly suggests that the presence of chlorides in the S1, S2 and S3 mixtures significantly increases the corrosion kinetics. In particular, the S1 deposit, which has the highest concentration of chlorides, is the most aggressive $\left(59.6 \mathrm{mg} / \mathrm{cm}^{2}\right)$ followed by the deposits S3 and S2 (42.7 and $34.1 \mathrm{mg} / \mathrm{cm}^{2}$, respectively). Different authors have demonstrated that the presence of chlorides causes severe damage and also accelerates corrosion through a mechanism usually called chlorine-induced "active oxidation" [24-26]. Although during the first steps of isothermal test the Na-containing S2 salt is more aggressive, the trend changes 
after $90 \mathrm{~h}$. The K-rich S3 deposit is in contrast more aggressive after $360 \mathrm{~h}$ of test. This could be associated with the presence of $\mathrm{KCl}$, which weakens the protective $\mathrm{Cr}$-rich oxide layer through the formation of either potassium chromate $\mathrm{K}_{2} \mathrm{CrO}_{4}$ or dichromate $\mathrm{K}_{2} \mathrm{Cr}_{2} \mathrm{O}_{7}$. Finally, the deposit S4 produced low corrosion rate, similar to that of reference sample S0. This could be due to two main reasons: (i) the absence of chlorides in S4 deposit and (ii) because it has a melting temperature well above $650{ }^{\circ} \mathrm{C}$. In contrast, the $\mathrm{S} 1, \mathrm{~S} 2$ and S3 deposits have chlorides and theoretical melting temperatures of 657,626 and $690{ }^{\circ} \mathrm{C}$, respectively [16-18]. This means that these deposits partially or totally melted during isothermal tests producing a severe attack. In relation with the S1 and S3 deposits, which have a melting point above $650^{\circ} \mathrm{C}$, Skrifvars et al. [27] showed that corrosion may take place below the melting temperature of the synthetic alkali salt when chlorine was present in their studied salt mixtures.

The effect of the different salt mixtures on the integrity of oxide scale layers and their possible spallation during time is reported in Fig 2(b). After $90 \mathrm{~h}$ of exposure, the trend of the curves is very similar to that of Fig. 2(a) because no delamination of the oxide scale occurred irrespective of the salt. However, the oxides start to delaminate beyond $90 \mathrm{~h}$ under all tested conditions, but spallation is more drastic on the Cl-containing S1, S2 and S3 deposits. Such enhanced spallation has been previously reported by Habib et al. [28]. They studied the high temperature corrosion behavior of NiCrAlY coatings on AISI 304 stainless steel at 650 and $700{ }^{\circ} \mathrm{C}$ using synthetic air $+1 \% \mathrm{Cl}_{2}$ and they suggested that chlorine alters the defect structure of the scale because chloride ions may replace oxygen ions increasing the concentration of cation vacancies. These vacancies precipitate as voids resulting in pitting and spalling of the scale. 

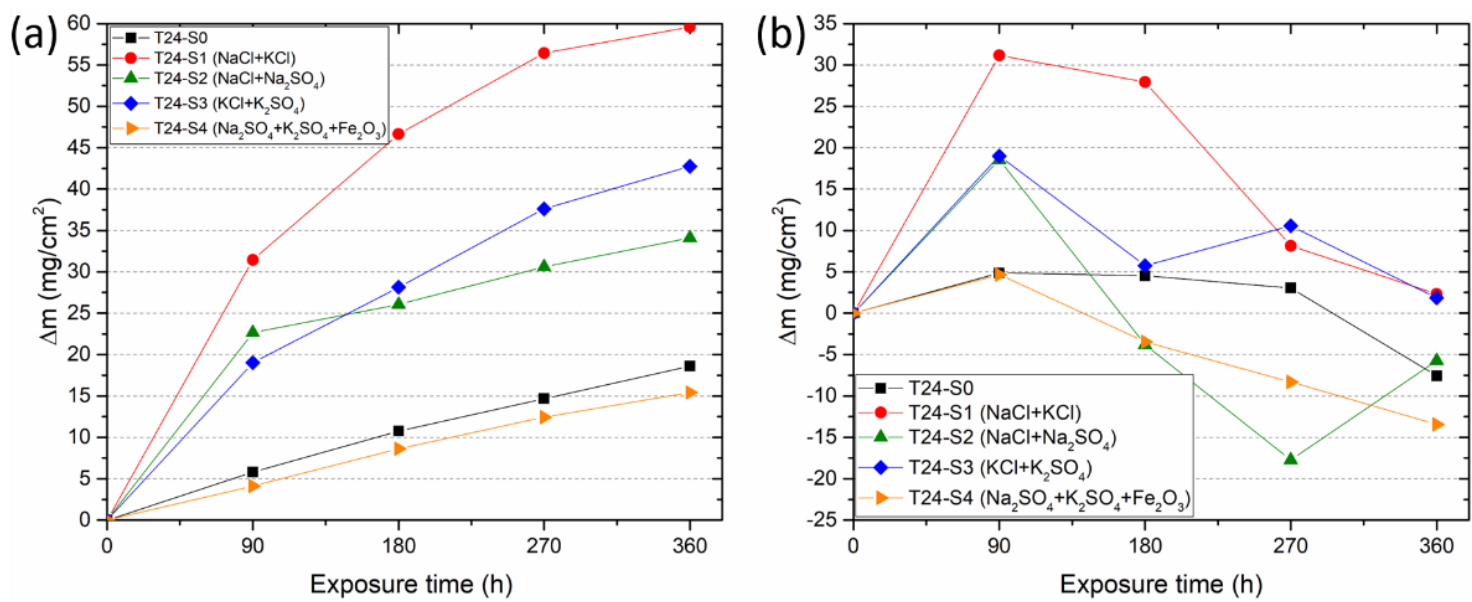

Fig 2 Evolution of mass variations of T24 steel substrate with time and salt mixture at $650{ }^{\circ} \mathrm{C}$ : (a) mass gain and (b) mass change without the spalled oxides.

\subsubsection{Dimensional metrology analysis}

Fig. 3(a) shows the metal loss or the equivalent thickness reduction data versus the cumulative probability for each tested sample of T24 steel exposed to different salt mixtures at $650{ }^{\circ} \mathrm{C}$ for $360 \mathrm{~h}$. The results indicate more corrosion damage on T24 steel in the presence of chlorides. At the median point (50\% cumulative probability), the metal loss is higher in the samples with the deposits $\mathrm{S} 1, \mathrm{~S} 2$ and $\mathrm{S} 3(604,463$ and $483 \mu \mathrm{m}$ metal loss, respectively) than in S0 and S4 (155 and $189 \mu \mathrm{m}$ metal loss, respectively). In addition, different trends can be observed in Fig. 3(a). The plots of samples exposed to S0 and S4 deposits are straight and the metal loss values are almost constant. This means that no localized attack was produced. However, the plots of samples exposed to S2 and S3 deposits show that approximately $75 \%$ of the sample underwent severe damage while $25 \%$ of the sample suffered less corrosion attack. Table 2 shows the average metal loss data of T24 steel exposed to the different salt mixtures from which the corrosion damage increases in the sequence $\mathrm{S} 0 \approx \mathrm{S} 4<\mathrm{S} 2 \approx \mathrm{S} 3<\mathrm{S} 1$. This ranking is the same as the one established from the gravimetric tests, with S1 again as the most aggressive deposit with an average metal loss of $638 \mu \mathrm{m}$ after $360 \mathrm{~h}$ exposure at $650{ }^{\circ} \mathrm{C}$. 
Fig 3(b) displays the metal loss (in $\mu \mathrm{m}$ ) versus the cumulative probability (in \%) of $\mathrm{NiCr}$ coatings exposed to the same salt mixtures for $360 \mathrm{~h}$. A huge reduction of the damage in the parent material was achieved compared to the uncoated one (Fig. 3(a)). However, the coatings themselves underwent severe damage in some conditions, as will be shown later by SEM. The highest attack occurs again in the presence of chlorides (Table 2) but no marked difference between the Cl-containing S1, S2 and S3 deposits can be made.
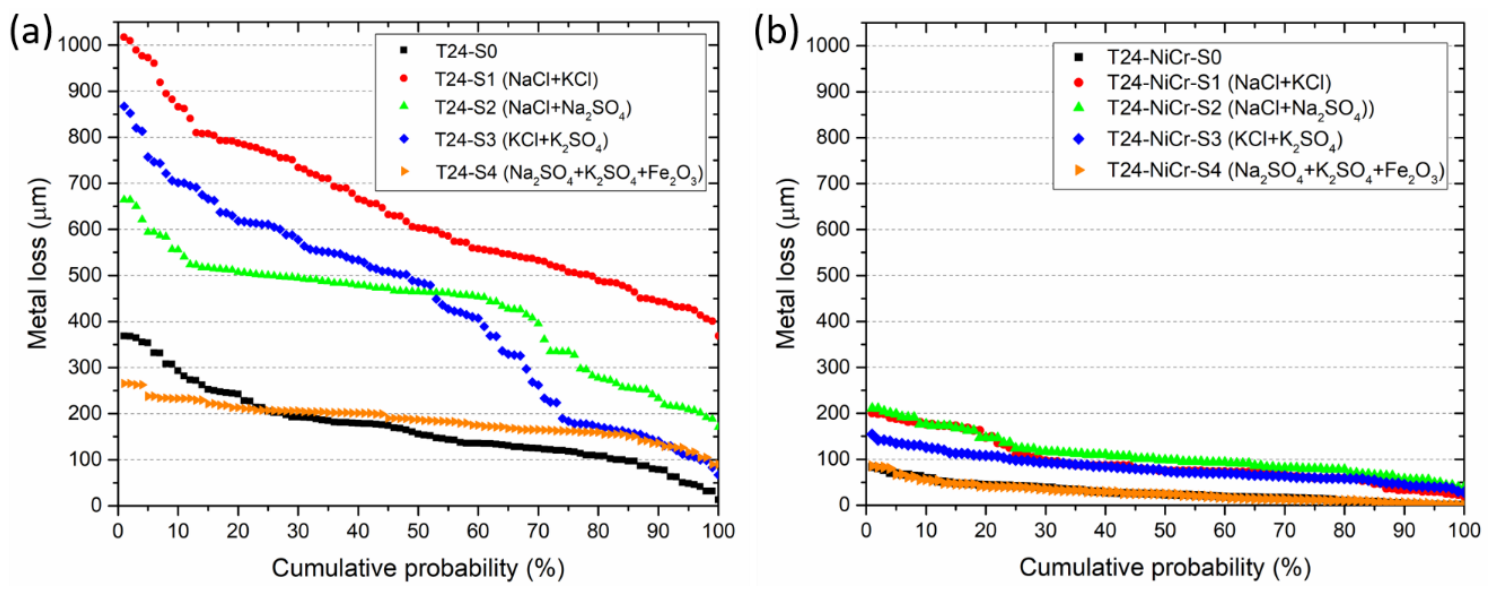

Fig 3 Measurement of metal loss $(\mu \mathrm{m})$ vs cumulative probability (\%) showing the behavior of (a) T24 steel substrate and (b) NiCr coating exposed to different salt mixtures at $650{ }^{\circ} \mathrm{C}$ for $360 \mathrm{~h}$.

Table 2 Comparison of the average metal loss $(\mu \mathrm{m})$ of $\mathrm{T} 24$ steel and $\mathrm{NiCr}$ coatings after their exposure to different salt mixtures.

\begin{tabular}{cccccc}
\hline Sample / Salt & S0 & S1 & S2 & S3 & S4 \\
\hline T24 & 169 & 638 & 424 & 431 & 185 \\
\hline NiCr coating & 23 & 92 & 107 & 80 & 27 \\
\hline
\end{tabular}

\subsection{XRD analysis after the corrosion tests}

Fig. 4(a) shows the main characteristic peaks of the steel substrate after exposure to the different deposits at $650^{\circ} \mathrm{C}$ for $360 \mathrm{~h}$. The S0 sample without any deposit shows the characteristic peaks of ferritic steel $(\alpha-\mathrm{Fe})$ and two iron oxides, mainly hematite $\left(\mathrm{Fe}_{2} \mathrm{O}_{3}\right)$ and magnetite $\left(\mathrm{Fe}_{3} \mathrm{O}_{4}\right)$. The peaks of $\alpha$-Fe disappeared when the steel was exposed to the 
different salts. The X-ray pattern of the samples exposed to the $\mathrm{S} 1$ deposit displays the peaks of salt mixtures $(\mathrm{NaCl}$ and $\mathrm{KCl})$, of iron oxides $\left(\mathrm{Fe}_{2} \mathrm{O}_{3}\right.$ and $\left.\mathrm{Fe}_{3} \mathrm{O}_{4}\right)$ and of sodium ferrite $\left(\mathrm{NaFeO}_{2}\right)$. The latter has been described by Soleimani et al. [29] as a typical corrosion product in molten salts. In our case, $\mathrm{NaFeO}_{2}$ could form from reaction between $\mathrm{NaCl}$ and $\mathrm{Fe}_{2} \mathrm{O}_{3}$ under oxidizing conditions according to Equation (1). Sodium ferrite is also accompanied by the formation of $\mathrm{Cl}_{2(\mathrm{~g})}[17,30]$. Therefore, the dominant corrosion mechanism involves (i) the initial production of chlorides, (ii) their subsequent diffusion through metal oxide layer and their reaction with the metal according to Equation (2) and (iii) the formation of volatile metal chlorides such as $\mathrm{FeCl}_{2}$ at the substrate/oxide layer interface, Equation (3).

$$
\begin{gathered}
2 \mathrm{NaCl}_{(l)(s)}+\mathrm{Fe}_{2} \mathrm{O}_{3(s)}+\frac{1}{2} \mathrm{O}_{2(g)} \leftrightarrow 2 \mathrm{NaFeO}_{2(s)}+\mathrm{Cl}_{2(g)} \\
\mathrm{Fe}_{(s)}+\mathrm{Cl}_{2(g)} \leftrightarrow \mathrm{FeCl}_{2(s)} \\
\mathrm{FeCl}_{2(s)} \leftrightarrow \mathrm{FeCl}_{2(g)}
\end{gathered}
$$

Otherwise, the X-ray patterns of the samples exposed to S2 and S4 deposits did not provide any additional information other than the presence of the salt mixtures. This suggests that the deposits did not fully react with the substrate at $650^{\circ} \mathrm{C}$. In addition, the XRD patterns of the samples exposed to S3 deposit revealed the exclusive formation of $\mathrm{Fe}_{2} \mathrm{O}_{3}$.

The XRD patterns of $\mathrm{NiCr}$ coating after exposure to the different salts at $650^{\circ} \mathrm{C}$ for 360 $\mathrm{h}$ are shown in Fig 4(b). The samples without any deposit S0 exhibit three major peaks of the austenitic $\mathrm{Y}-\mathrm{Ni}$ and some small peaks associated with $\mathrm{Cr}_{2} \mathrm{O}_{3}$ and $\mathrm{NiCr}_{2} \mathrm{O}_{4}$ spinel. After reaction with the $\mathrm{S} 1$ deposit, the patterns now include peaks of the salt mixture $(\mathrm{NaCl}$ and $\mathrm{KCl})$ and of a new phase identified as potassium chromate $\left(\mathrm{K}_{2} \mathrm{CrO}_{4}\right)$, in addition to the $\mathrm{Cr}_{2} \mathrm{O}_{3}$ and $\mathrm{NiCr}_{2} \mathrm{O}_{4}$. Otherwise, the peaks of $\mathrm{Na}_{2} \mathrm{SO}_{4}, \mathrm{NaCl}$ and $\mathrm{NiCr}_{2} \mathrm{O}_{4}$ spinel are 
revealed in the sample with S2 deposit. In contrast, no reflections from the S3 salt appear but just the peaks of $\mathrm{Cr}_{2} \mathrm{O}_{3}, \mathrm{NiCr}_{2} \mathrm{O}_{4}$ and $\mathrm{K}_{2} \mathrm{CrO}_{4}$. The latter, shown also in the samples exposed to $\mathrm{S} 1$ deposit, is a bright yellow precipitate [31] formed by the reaction of chromium oxides with $\mathrm{KCl}$, as different authors pointed out in connection to chlorineinduced high temperature corrosion [32]. As for the sample with the S4 deposit, the peaks of $\mathrm{Cr}_{2} \mathrm{O}_{3}$ and of the deposit mixture $\left(\mathrm{Na}_{2} \mathrm{SO}_{4}, \mathrm{~K}_{2} \mathrm{SO}_{4}\right.$ and $\left.\mathrm{Fe}_{2} \mathrm{O}_{3}\right)$ can be unambiguously identified.
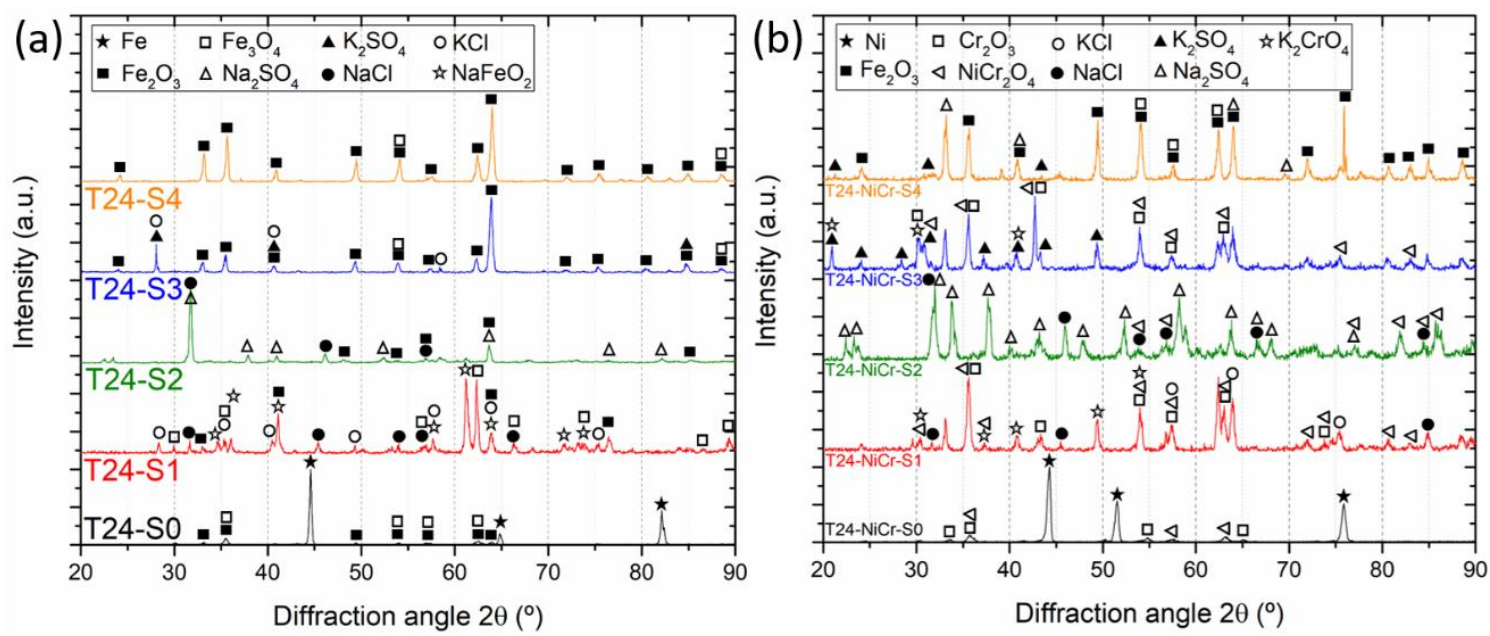

Fig 4 XRD patterns after high temperature corrosion tests in presence of different salt mixture at $650{ }^{\circ} \mathrm{C}$ for 360 h of: (a) T24 steel substrate and (b) NiCr coated steel substrate.

\subsection{Microstructural characterization}

\subsubsection{Samples without salts}

The high temperature corrosion resistance of the NiCr-coated and the uncoated $\mathrm{T} 24$ steel exposed to air at $650{ }^{\circ} \mathrm{C}$ for $360 \mathrm{~h}$ was analyzed in detail in a previous study [19]. The uncoated steel grew a non-protective oxide layer composed of an inner layer of $\mathrm{Fe}_{3} \mathrm{O}_{4}$ and an outer scale of $\mathrm{Fe}_{2} \mathrm{O}_{3}$ of around $120 \mu \mathrm{m}$. In some areas, this solid layer suffered spallation from metal surface. In contrast, the NiCr coating protected the steel substrate through the formation of a thin layer of protective $\mathrm{Cr}_{2} \mathrm{O}_{3}$ oxide and $\mathrm{NiCr}_{2} \mathrm{O}_{4}$ spinel. The 
microstructural analysis did not reveal any damage neither in the coating nor in the substrate after $360 \mathrm{~h}$ exposure in air without salt at $650^{\circ} \mathrm{C}$.

\subsubsection{Samples exposed to the $\mathrm{NaCl}-\mathrm{KCl}$ salt mixture}

Fig. 5 shows SEM micrograph of the surface of T24 steel exposed to $\mathrm{NaCl}-\mathrm{KCl}$ salt mixture (S1 deposit). Fig. 5 reveals two different areas, the external area marked with (1) corresponds to an oxide layer completely cracked formed by iron oxides while the inner area marked with (2) is the surface after spallation of the oxide. The spot EDX analyses (not shown in Fig 5) indicate the presence of salt elements ( $\mathrm{Na}, \mathrm{Cl}$ and $\mathrm{K}$ ) as well as of Fe and $\mathrm{O}$.

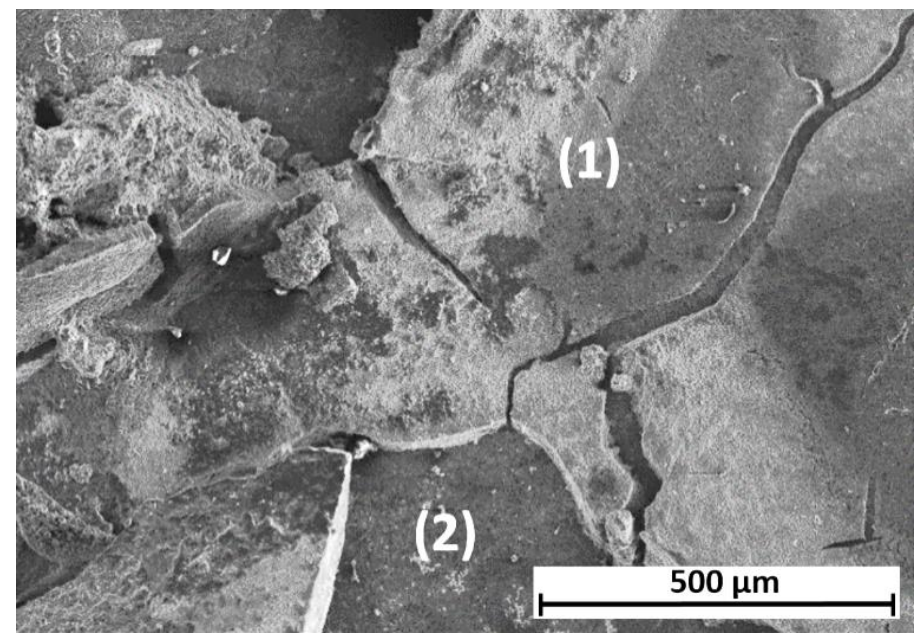

Fig $5 \mathrm{SEM}$ micrograph of the surface of $\mathrm{T} 24$ steel exposed to the $\mathrm{NaCl}-\mathrm{KCl}$ salt mixture at $650{ }^{\circ} \mathrm{C}$ for $360 \mathrm{~h}$.

The cross-section (Fig. 6a) shows the oxide layers and the underlying metal partially attacked. The internal layer is rich in $\mathrm{Cl}, \mathrm{O}, \mathrm{Na}$ and $\mathrm{K}$ according to the $\mathrm{X}$-ray maps. The external oxide layer is mainly formed by $\mathrm{Fe}_{3} \mathrm{O}_{4}$ and $\mathrm{Fe}_{2} \mathrm{O}_{3}$, as revealed at higher magnification (Fig. 6b). This non-protective oxide layer seems cracked and spalled all throughout the sample surface. In addition, the dark corrosion products can be clearly seen in Fig. 6(c). The EDX analyses and the XRD reveal Cl-K-Na rich products and 
$\mathrm{NaFeO}_{2}$, which is a typical corrosion product of iron based alloys in molten salts $[29,33]$.

It thus appears that the $\mathrm{Cl}_{2(\mathrm{~g})}$ released upon the reaction of the alkali chlorides with iron oxide (Equation (1)) diffuse through the non-protective porous and cracked Fe-rich oxides to the oxides-metal interface leading to the formation of iron chloride $\left(\mathrm{FeCl}_{2(\mathrm{~s})}\right)$. The high volatility of the iron chloride brings about its diffusion backwards $\left(\mathrm{FeCl}_{2(\mathrm{~g})}\right)$ through the non-protective Fe-rich oxide layer [34].

Once a sufficient oxygen partial pressure $\left(\mathrm{P}_{\mathrm{O} 2}\right)$ is reached, the chlorides destabilize and form $\mathrm{Fe}_{2} \mathrm{O}_{3}$, while $\mathrm{Cl}_{2(\mathrm{~g})}$ regenerates following Equation (4). These reaction steps are endlessly repeated causing severe damage [30], let alone that corrosion is fostered through the alloy grain boundaries (Fig. 6d) as also demonstrated upon chromizing an austenitic AISI 304 stainless steel due to the volatilization of $\mathrm{FeCl}_{2}$ [35].

$$
2 \mathrm{FeCl}_{2(g)}+\frac{3}{2} \mathrm{O}_{2(g)} \leftrightarrow \mathrm{Fe}_{2} \mathrm{O}_{3(s)}+2 \mathrm{Cl}_{2(g)}
$$

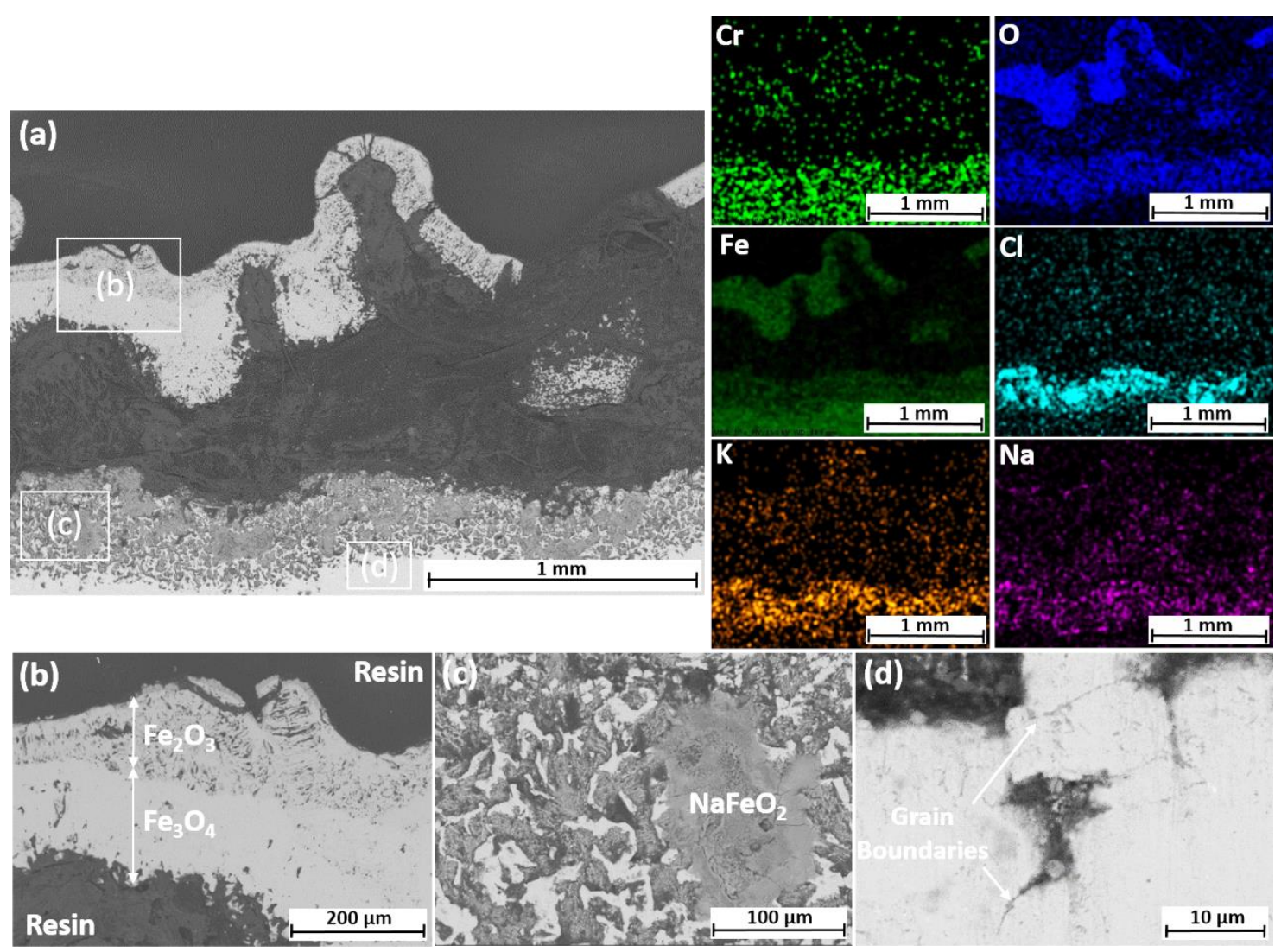


Fig 6 SEM micrographs of T24 steel exposed to the $\mathrm{NaCl}-\mathrm{KCl}$ salt mixture at $650^{\circ} \mathrm{C}$ for $360 \mathrm{~h}$ : (a) EDX maps analysis of the cross-section and (b-d) three micrographs at higher magnification of different zones marked in figure (a).

Fig. 7(a) shows the cross-sectional analysis of the $\mathrm{NiCr}$ coating after exposure to the $\mathrm{NaCl}-\mathrm{KCl}$ salt mixture at $650^{\circ} \mathrm{C}$ for $360 \mathrm{~h}$. It seems that the coating maintains its structural integrity despite the great penetration of the salts. In addition to coating composition, the microstructural features of the coating processed by HVOF, i.e. inclusions of oxides, porosity content or splat boundaries are also important when assessing their effectiveness at high temperatures [36]. This is demonstrated in Fig 7(b) where the aggressive salts progressed easily between the splat boundaries. In addition, the clustered particles are corroded along the interface between the grains. This phenomenon is only observed at the outer part of the coating, because these external semimolten particles are less compact. The EDX maps reveal that $\mathrm{Cr}$ diffuses through each particle generating a layer of $\mathrm{Cr}_{2} \mathrm{O}_{3}$ between them. However, the salts seem to induce corrosion through two major steps: (i) the $\mathrm{K}$ reacts with the protective $\mathrm{Cr}$-rich oxides forming $\mathrm{K}_{2} \mathrm{CrO}_{4}$ that weakens the $\mathrm{Cr}$-rich oxide layer and (ii) the weakened chromia layer leaves an easy-accessible pathway for chlorides to advance through the coating. 


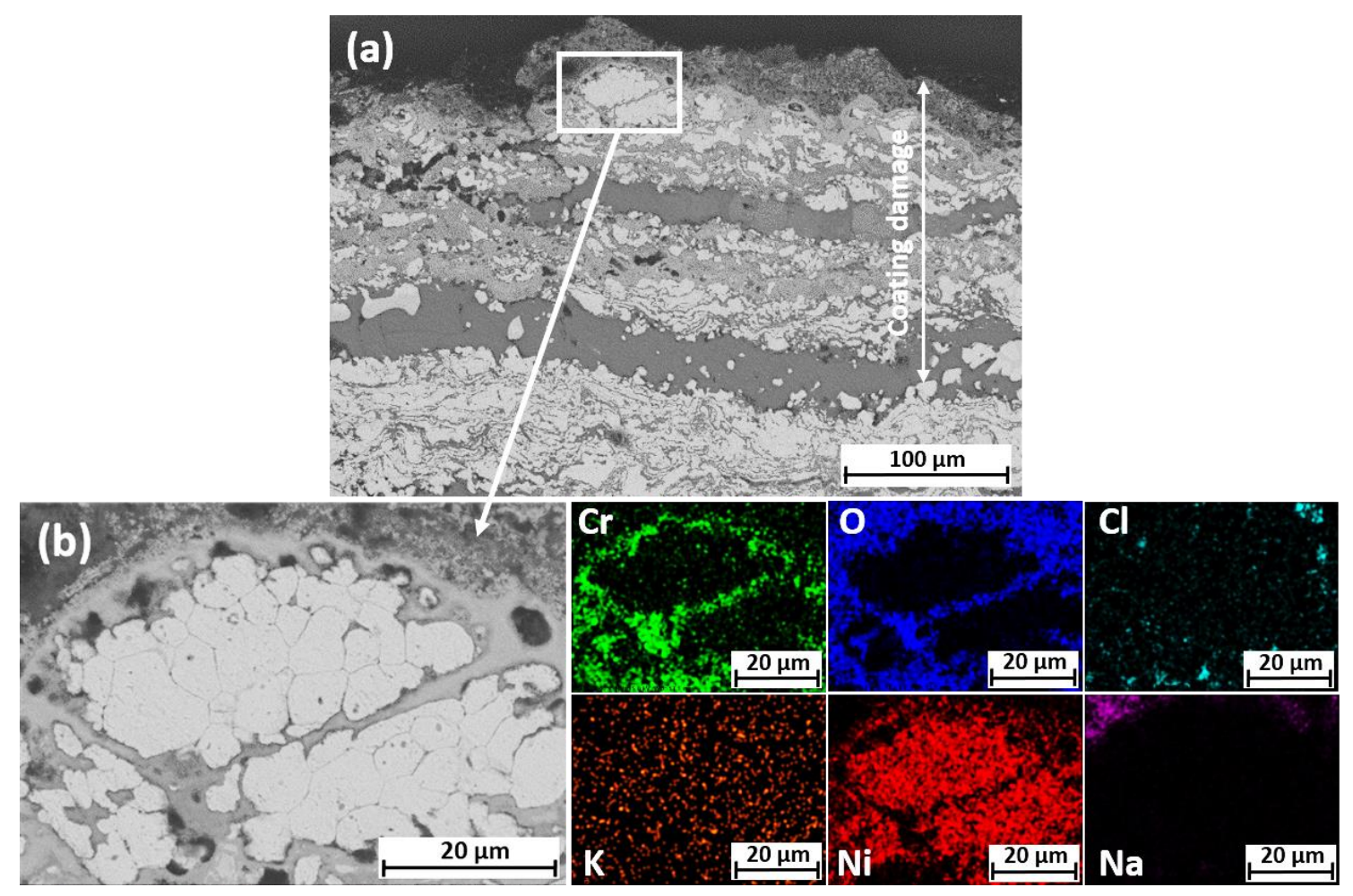

Fig $7 \mathrm{SEM}$ micrographs of $\mathrm{NiCr}$ coating exposed to the $\mathrm{NaCl}-\mathrm{KCl}$ salt mixture at $650^{\circ} \mathrm{C}$ for $360 \mathrm{~h}$. Crosssectional analysis at (a) x300 and (b) x2000 magnification with EDX map analyses.

\subsubsection{Samples exposed to the $\mathrm{NaCl}-\mathrm{Na}_{2} \mathrm{SO}_{4}$ salt mixture}

Fig. 8(a) shows a typical SEM micrograph of T24 steel surface exposed to $\mathrm{NaCl}-\mathrm{Na}_{2} \mathrm{SO}_{4}$ salt mixture deposit. Contrary to what occurred with the previous S1 mixed chlorides deposit, T24 steel does not have a spalled oxide layer full of cracks in the surface. In contrast, a dense oxide layer was observed. Moreover, the cross-sectional analysis did not reveal either severe damage or detachment of the oxide scale layer (Fig. 8b). A multilayer oxide scale composed by different phases is readily observed in the chemical distribution maps of Fig. 8(b). From the gas interface towards the substrate, the multilayer is formed by: (1) a layer rich in salts, (2) $\mathrm{Fe}_{2} \mathrm{O}_{3}$, (3) a second layer rich in salts, (4) Fe-Cr spinels and (5) an inner layer rich in S. Since the Na distribution appears in the same locations as $\mathrm{S}$, it seems that this multilayer microstructure arises from the deposit-recoating method employed in this study. However, no chlorides were observed at the interface between 
the oxide layer and the steel substrate. This suggests that the very thick Fe-rich oxide layer formed at $650^{\circ} \mathrm{C}$ for $360 \mathrm{~h}$ is able to limit the penetration of chlorides until the substrate-oxide layer interface.

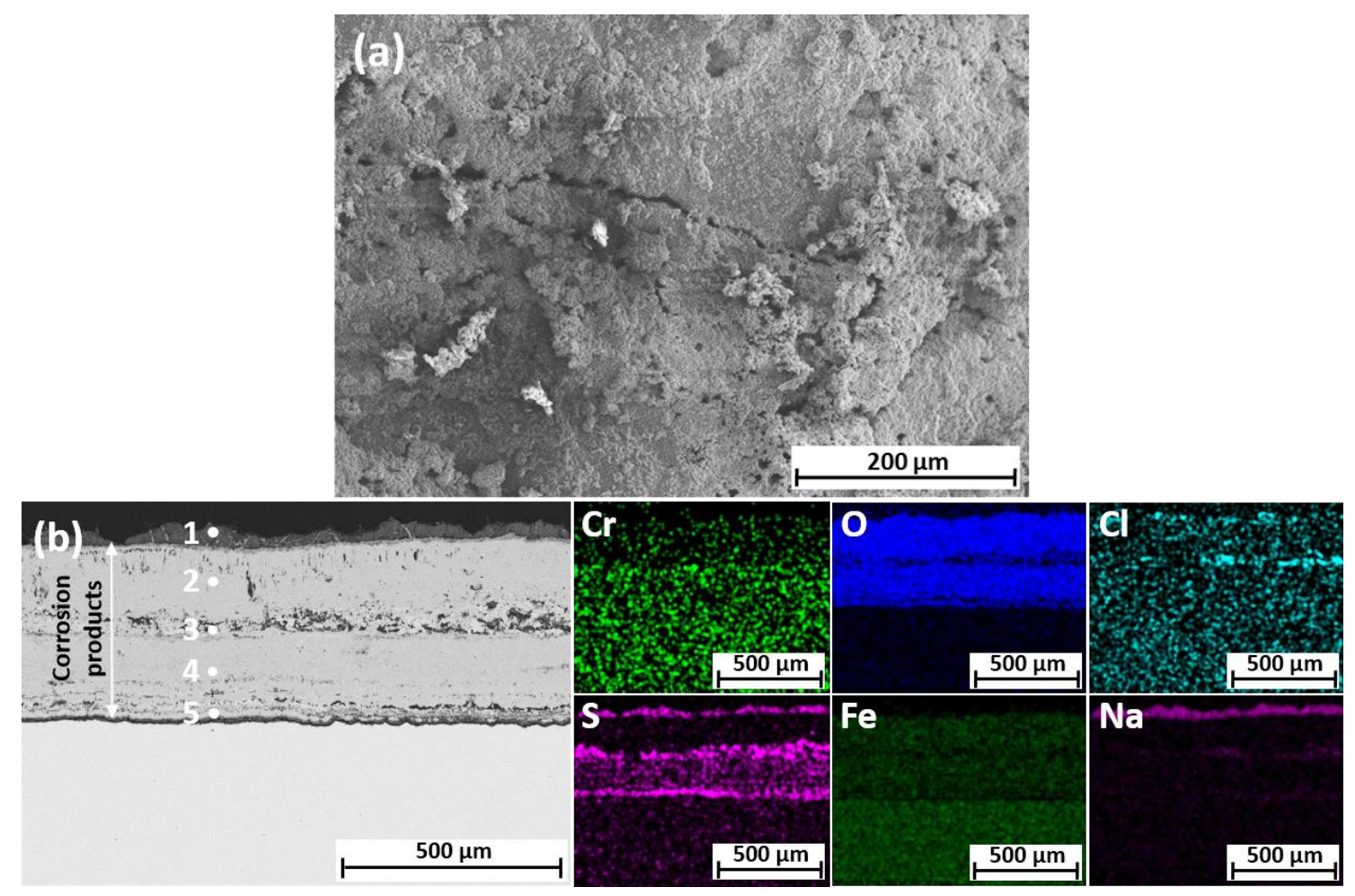

Fig 8 SEM micrographs of T24 steel exposed to $\mathrm{NaCl}-\mathrm{Na}_{2} \mathrm{SO}_{4}$ salt mixture at $650^{\circ} \mathrm{C}$ for $360 \mathrm{~h}$ : (a) sample surface and (b) EDX spot and mapping analysis of the cross-section.

Fig. 9 illustrates the SEM cross-section of the $\mathrm{NiCr}$ coating exposed to $\mathrm{NaCl}-\mathrm{Na}_{2} \mathrm{SO}_{4}$ salt mixture. Compared to the previous S1 chlorides deposit, there was less penetration of the salts, although the attack was still very aggressive. The dark Cl-rich corrosion products inside the coating can be readily observed, as in the case of the S1 chloride deposit. Salt mixture attack was particularly rapid near splat boundaries where the oxides were present. 


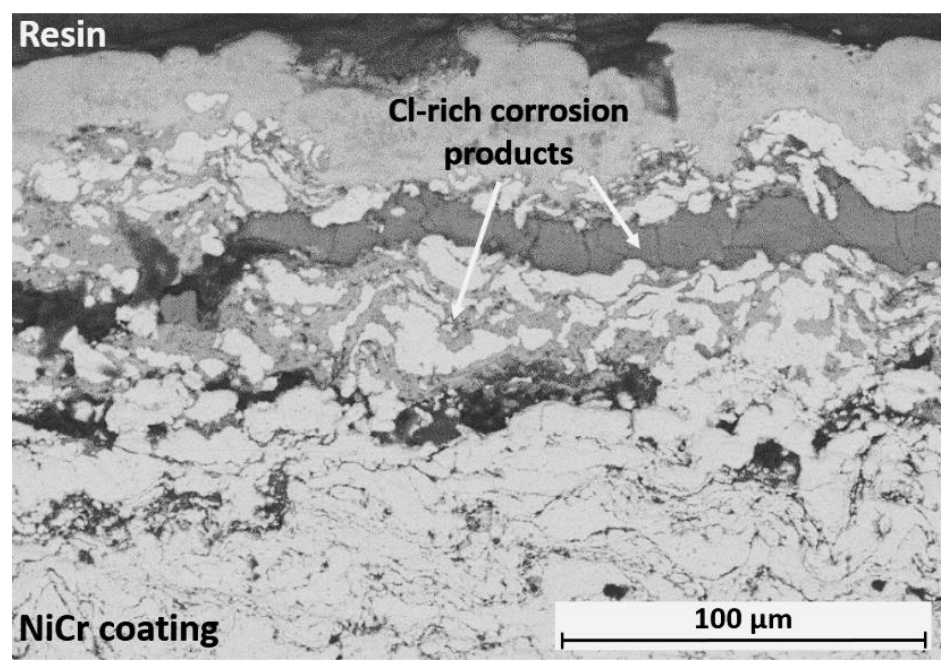

Fig $9 \mathrm{SEM}$ micrograph of $\mathrm{NiCr}$ coating exposed to $\mathrm{NaCl}-\mathrm{Na}_{2} \mathrm{SO}_{4}$ mixture deposit at $650^{\circ} \mathrm{C}$ for $360 \mathrm{~h}$.

\subsubsection{Samples exposed to the $\mathrm{KCl}-\mathrm{K}_{2} \mathrm{SO}_{4}$ salt mixture}

Fig. 10(a) shows SEM plain view micrographs of T24 steel surface exposed to the $\mathrm{KCl}$ $\mathrm{K}_{2} \mathrm{SO}_{4}$ salt mixture. Similar to the sample with the $\mathrm{S} 2$ chloride/sulfate deposit, the Ferich oxide layer maintained the integrity and underwent less spallation than the sample solely exposed to chlorides (S1). Rough and smooth areas with different chemistry can be observed. Indeed, the smoother surface contains only Fe and $\mathrm{O}$, while the constituents of the salt and $\mathrm{Fe}$ and $\mathrm{O}$ are detected in the EDX spectra of the rough areas. At higher magnification, insert in Fig. 9(a), the rough surface shows octahedral crystals, which can be associated with iron oxides. The high melting point of this salt $\left(690{ }^{\circ} \mathrm{C}\right)$ and its heterogeneous distribution along substrate surface suggests that the salt partially melted, so that the attack proceeded with the salt in semi-solid condition. In agreement with the opinion of Skrifvars et al. [37], it is though assumed that the molten phase gives a better contact between the salt particles and the steel surface that results in greater corrosive attack than when the salts are still solid. Fig. 9(b) shows the presence of salts below the Fe-rich oxide layer, as in the samples exposed to the $\mathrm{S} 1$ chlorides deposit. In addition, some chlorides can be observed at the interface between the oxide layer and the steel 
substrate. At higher magnification, the penetration of the chlorides into the steel substrate (marked with arrows) can be readily observed in Fig. 10(b). A low amount of chlorides seems to trigger the active oxidation mechanism and $\mathrm{K}$ seems to accelerate it.
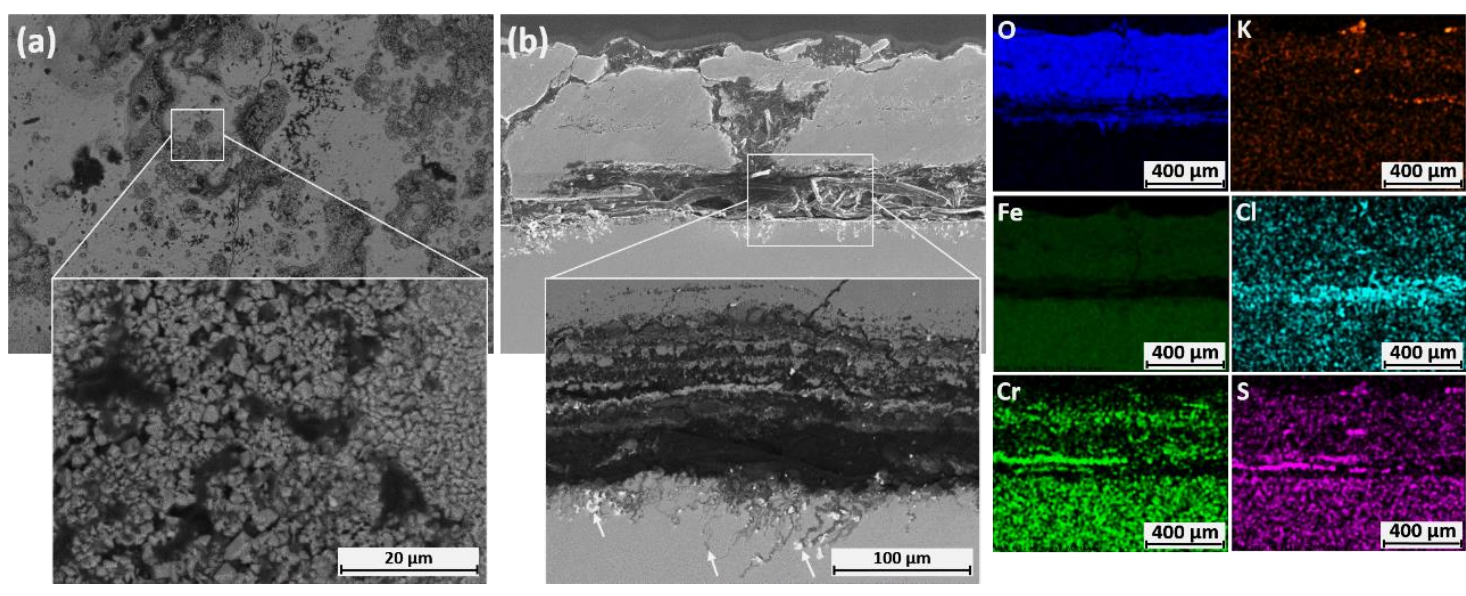

Fig $10 \mathrm{SEM}$ micrographs of $\mathrm{T} 24$ steel exposed to the $\mathrm{KCl}-\mathrm{K}_{2} \mathrm{SO}_{4}$ salt mixture at $650^{\circ} \mathrm{C}$ for $360 \mathrm{~h}$ : (a) sample surface and (b) cross-section micrograph and EDX map analyses.

Fig. 11(a) collects the SEM micrographs and the X-ray maps of the NiCr coating exposed to the $\mathrm{KCl}-\mathrm{K}_{2} \mathrm{SO}_{4}$ salt mixture. The coating seems to maintain the integrity and a good adherence to the substrate. However, severe damage occurs at the outermost area of the coating as shown at higher magnification in Fig. 11(b). It has some cracks normal to the gas/coating interface, which are often associated with tensile stresses due to the mismatch in the thermal expansion coefficients of the constituent of the layers [38]. Such chemical differences through the layers are clearly shown in the EDX analyses. The outermost layer is rich in $\mathrm{K}_{2} \mathrm{SO}_{4}$. The second layer is rich in $\mathrm{Cr}$, $\mathrm{O}$ and $\mathrm{K}$, suggesting the formation of the $\mathrm{K}_{2} \mathrm{CrO}_{4}$ previously detected by $\mathrm{XRD}$ analysis. The third layer is rich in $\mathrm{Ni}, \mathrm{Cr}$ and $\mathrm{O}$ in line with the $\mathrm{NiCr}_{2} \mathrm{O}_{4}$ spinel and $\mathrm{Cr}_{2} \mathrm{O}_{3}$ identified by XRD. The $\mathrm{Cr}$-poor layer below the Ni-Cr-rich layers likely occurs by chlorination because the enthalpy of formation of $\mathrm{CrCl}_{3(\mathrm{~g})}$ is favored with respect $\mathrm{NiCl}_{2(\mathrm{~g})}$ [39]. The reaction between $\mathrm{Ni}$ and $\mathrm{Cl}_{2}$ is less thermodynamically favored than the reaction between $\mathrm{Cr}$ with $\mathrm{Cl}_{2}$, because the free energy of Ni-chlorides formation is less than that of Cr-chlorides $(-371.6 \mathrm{~kJ} / \mathrm{mol}$ for 
$\mathrm{CrCl}_{3}$ and $-174 \mathrm{~kJ} / \mathrm{mol}$ for $\mathrm{NiCl}_{2}$ at $600{ }^{\circ} \mathrm{C}$ ). In our view, the chlorination occurs deep in the coating because the $\mathrm{P}_{\mathrm{O} 2}$ is too low to form any chromium oxide while that of $\mathrm{P}_{\mathrm{Cl} 2}$ increases. As a result, the coating becomes severely damaged. These results agree with the studies of Varis et al. [40], who also observed a heavily Cr-depleted layer of their thermally sprayed $\mathrm{NiCr}$ coating exposed to a $\mathrm{KCl}-\mathrm{K}_{2} \mathrm{SO}_{4}$ salt mixture at $600{ }^{\circ} \mathrm{C}$ and with the studies of Sadeghimeresht et al. [39]. The latter also observed $\mathrm{Cr}$ depletion in their NiCrAlY and NiCrMo coatings at $600{ }^{\circ} \mathrm{C}$. They observed voids distributed mainly beneath the top formed oxide scale produced by the vaporization of metallic chlorides $\left(\mathrm{CrCl}_{3}\right.$ and $\left.\mathrm{CrCl}_{2}\right)$. In our case, these voids were observed largely beneath the top formed oxide scale because our testing temperature $\left(650^{\circ} \mathrm{C}\right)$ is higher than theirs $\left(600^{\circ} \mathrm{C}\right)$ [33]. In contrast, the inner part of the coating seems to be unaffected after $360 \mathrm{~h}$ of exposure. This reveals that the access of chlorine to deeper zones is hampered by the tortuosity created by the splats of the coating.

According to these results, the corrosion mechanism may in essence occur following the sequence: (i) formation of protective $\mathrm{NiCr}_{2} \mathrm{O}_{4}$ and $\mathrm{Cr}_{2} \mathrm{O}_{3}$ oxides at $650^{\circ} \mathrm{C}$; (ii) formation of $\mathrm{K}_{2} \mathrm{CrO}_{4}$ according to Equation (5); (iii) the presence of $\mathrm{K}_{2} \mathrm{SO}_{4}$ enhances the break-up of the protecting oxide layer and, finally, (iv) $\mathrm{Cr}-\mathrm{Cl}$ rich $\left(\mathrm{CrCl}_{3}\right)$ inter-lamellar inclusions were formed in the area which leads to a heavy depletion of $\mathrm{Cr}$.

$$
4 \mathrm{KCl}_{(s)(l)}+\mathrm{Cr}_{2} \mathrm{O}_{3(s)}+\frac{5}{2} \mathrm{O}_{2(g)} \leftrightarrow 2 \mathrm{~K}_{2} \mathrm{CrO}_{4(s)}+2 \mathrm{Cl}_{2(g)}
$$

Pettersson et al. [32] studied the effect of $\mathrm{KCl}$ and $\mathrm{K}_{2} \mathrm{SO}_{4}$ on the corrosion of 304 stainless steel at $600^{\circ} \mathrm{C}$ and also showed the formation of $\mathrm{K}_{2} \mathrm{CrO}_{4}$ under $\mathrm{KCl}$ rich deposits. They proposed that $\mathrm{K}_{2} \mathrm{SO}_{4}$ does not accelerate the corrosion significantly and that $\mathrm{KCl}$ is the main cause of the attack. Despite the clear differences between the 304 steel and our $\mathrm{NiCr}$ coatings, both possess austenitic matrices and the $\mathrm{Cr}$ contents are about the same ( 18 vs. 
$20 \mathrm{wt} \%$, respectively). Therefore, our findings compare rather well even if our temperatures $\left(650^{\circ} \mathrm{C}\right)$ are higher $\left(600^{\circ} \mathrm{C}\right)$ than theirs.
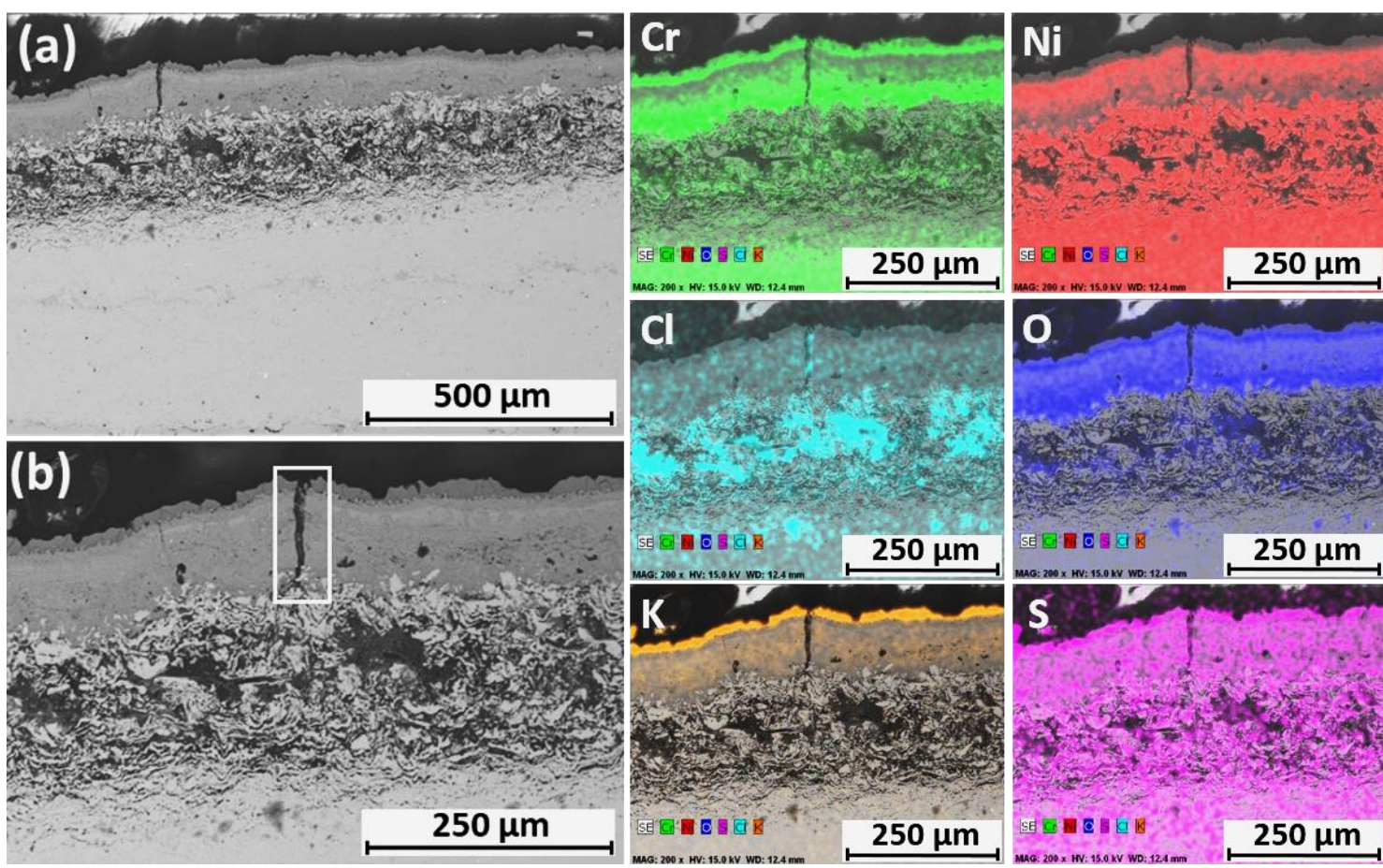

Fig 11 SEM micrographs of NiCr coating exposed to the $\mathrm{KCl}-\mathrm{K}_{2} \mathrm{SO}_{4}$ salt mixture at $650^{\circ} \mathrm{C}$ for $360 \mathrm{~h}$ at different magnifications: (a) x100 and (b) x200 with an EDX maps.

\subsubsection{Samples under $\mathrm{Na}_{2} \mathrm{SO}_{4}-\mathrm{K}_{2} \mathrm{SO}_{4}-\mathrm{Fe}_{2} \mathrm{O}_{3}$ salt mixture}

Fig. 12(a) shows SEM micrographs of T24 steel exposed to $\mathrm{Na}_{2} \mathrm{SO}_{4}-\mathrm{K}_{2} \mathrm{SO}_{4}-\mathrm{Fe}_{2} \mathrm{O}_{3}$ salt mixture. The steel matrix has barely suffered any damage probably because of the absence of chlorides. The attack initiates through the grain boundaries shown by the arrow marks in Fig. 12(a). However, the attack does not seem severe after $360 \mathrm{~h}$ of exposure at $650{ }^{\circ} \mathrm{C}$ compared with the other deposits. Furthermore, the NiCr coating exposed to the $\mathrm{S} 4$ sulfates/oxides mixture does not exhibit any attack (Fig 12(b)). 

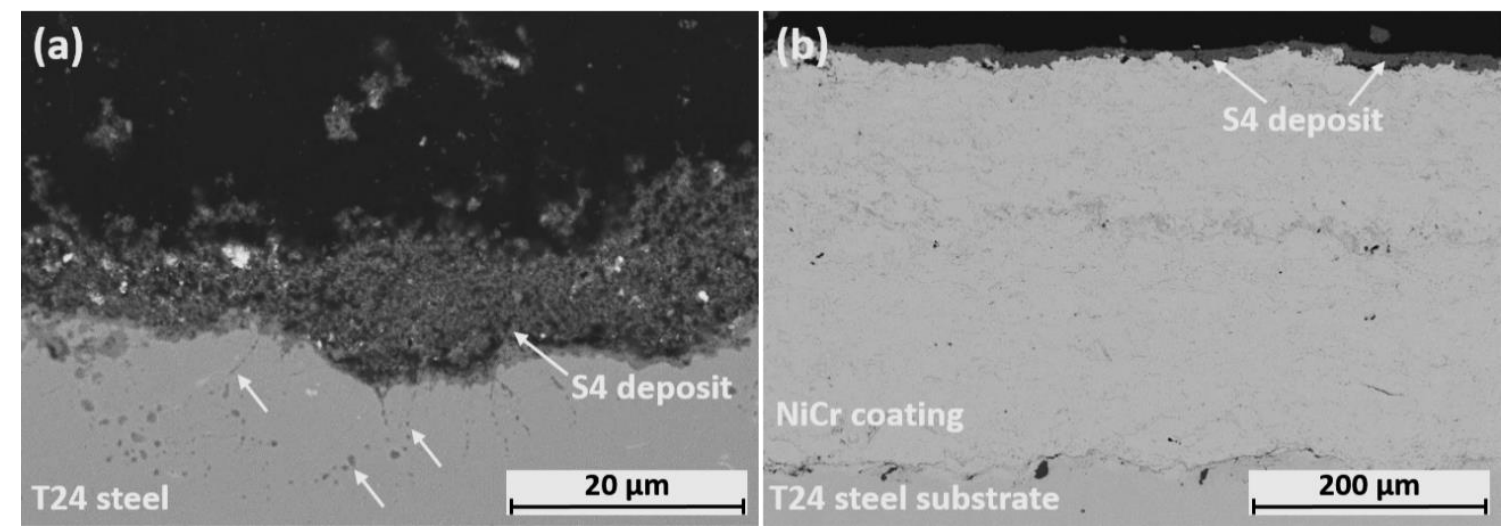

Fig 12 SEM micrographs of (a) T24 steel and (b) NiCr coating, exposed to the $\mathrm{Na}_{2} \mathrm{SO}_{4}-\mathrm{K}_{2} \mathrm{SO}_{4}-\mathrm{Fe}_{2} \mathrm{O}_{3}$ salt mixture at $650^{\circ} \mathrm{C}$ for $360 \mathrm{~h}$.

\subsection{Role of the salts}

The composition of the salts clearly affects the corrosion behavior of the uncoated and the NiCr-coated T24 steel. As such, the corrosivity of the salts can be ranked from the least to the most aggressive $(\mathrm{S} 0 \approx \mathrm{S} 4<\mathrm{S} 2 \approx \mathrm{S} 3<\mathrm{S} 1)$. The samples exposed to $\mathrm{S} 4$ deposit maintained their integrity because in under the current experimental conditions $\left(650^{\circ} \mathrm{C}\right.$, air atmosphere and $360 \mathrm{~h}$ exposure), both $\mathrm{K}$ and $\mathrm{Na}$ sulfates did not react with the samples avoiding the formation of metallic sulfates, such as $\mathrm{NiSO}_{4}$ that form eutectic compositions with the alkali sulfates. According to Xue-mei et al. [41], the melting points of $\mathrm{K}_{2} \mathrm{SO}_{4}-\mathrm{NiSO}_{4}$ and $\mathrm{Na}_{2} \mathrm{SO}_{4}-\mathrm{NiSO}_{4}$ eutectics range from 550 to $700{ }^{\circ} \mathrm{C}$. Furthermore, the eutectic of $\mathrm{Na}_{2} \mathrm{SO}_{4}-\mathrm{K}_{2} \mathrm{SO}_{4}-\mathrm{NiSO}_{4}$ is much lower. As in our case, they did not identify the formation of metallic sulfates when air atmosphere was employed. They reported the formation of $\mathrm{NiSO}_{4}$ only when $\mathrm{SO}_{3(\mathrm{~g})}$-rich atmosphere was employed. For low alloyed steels, other authors $[42,43]$ reported that at this temperature $\left(650{ }^{\circ} \mathrm{C}\right), \mathrm{Na}_{2} \mathrm{SO} 4-\mathrm{K}_{2} \mathrm{SO}_{4}$ mixture reacts with surface oxides in the presence of $\mathrm{SO}_{3}$ to form complex liquid sulfates $\left(\mathrm{Na}_{3} \mathrm{Fe}\left(\mathrm{SO}_{4}\right)_{3}\right.$ or $\left.\mathrm{K}_{3} \mathrm{Fe}\left(\mathrm{SO}_{4}\right)_{3}\right)$ that result in rapid corrosion. However, in this work, there is no aggressive atmosphere containing $\mathrm{SO}_{3}$ and the $\mathrm{P}_{\mathrm{SO} 3}$ is too low to make both $\mathrm{Na}_{2} \mathrm{SO}_{4} / \mathrm{K}_{2} \mathrm{SO}_{4}$ salts alive. Therefore, oxidation was the main mechanism occurring on 
the samples exposed to S4 deposit and the presence of $\mathrm{Na}$ and $\mathrm{K}$ sulfates did not accelerate the attack in the studied conditions.

According to the results obtained for S4 deposit, it can be derived that the damage suffered by the samples exposed to the S2 and S3 deposits was mainly induced by the presence of $\mathrm{NaCl}$ and $\mathrm{KCl}$, respectively. The samples exposed to the $\mathrm{S} 3$ deposit were slightly more attacked than the samples exposed to S2 deposit probably because of two main factors: (i) the higher presence of chlorides in S3 than in S2 deposit and (ii) the greatest aggressiveness of $\mathrm{K}$ than of Na. Indeed, $\mathrm{K}_{2} \mathrm{CrO}_{4}$ has been identified and it is assumed that it enhanced the break-up of the protective $\mathrm{Cr}_{2} \mathrm{O}_{3}$ layer. However, the difference is quite small because if their melting temperatures are taken into account the $\mathrm{S} 2$ deposit was completely melted $\left(\mathrm{T}_{\mathrm{m}}=626^{\circ} \mathrm{C}\right)$ under our testing conditions while the $\mathrm{S} 3$ deposit would be probably partially melted $\left(\mathrm{T}_{\mathrm{m}}=690^{\circ} \mathrm{C}\right)$. It thus seems that the $\mathrm{T} 24$ steel and the NiCr coating underwent both electrochemical and chlorine-induced active oxidation mechanisms during the exposure to S2 and S3 deposits.

In light of the obtained results, S1 was the most aggressive deposit because it presented the highest chlorides concentration and its melting temperature was near to that employed in this study. The high concentration of chlorides increased the $\mathrm{P}_{\mathrm{Cl} 2(\mathrm{~g})}$ against the $\mathrm{P}_{02(\mathrm{~g})}$ and favored the formation of metallic chlorides $\left(\mathrm{FeCl}_{2(\mathrm{~s})}\right.$ for the $\mathrm{T} 24$ steel and $\mathrm{CrCl}_{3(\mathrm{~s})}$ for the $\mathrm{NiCr}$ coating) at the substrate or coating /oxide layer interface. The high concentration of chlorides was evidenced by the formation of different species as $\mathrm{NaFeO}_{2}$ in the uncoated samples or $\mathrm{K}_{2} \mathrm{CrO}_{4}$ in the $\mathrm{NiCr}$ coating. The volatility of the metallic chloride brings about its diffusion backwards oxide scale and once a sufficient $\mathrm{P}_{\mathrm{O} 2}$ is reached, the chlorides destabilize and form again $\mathrm{Cl}_{2(\mathrm{~g})}$. Therefore, in the presence of $\mathrm{S} 1$ deposit, the main corrosion mechanism is chlorine-induced active oxidation.

\section{CONCLUSIONS}


- The aggressiveness of the different salt mixtures would follow the sequence $\mathrm{S} 0 \approx$ $\mathrm{S} 4<\mathrm{S} 2 \approx \mathrm{S} 3<\mathrm{S} 1$

- The $\mathrm{NaCl}-\mathrm{KCl}$ (S1) deposit was the most aggressive because it has the highest concentration of chlorides. The presence of $\mathrm{NaFeO}_{2}$ in substrate samples and of $\mathrm{K}_{2} \mathrm{CrO}_{4}$ in NiCr-coated samples evidenced that $\mathrm{Cl}_{2}(\mathrm{~g})$ favored the formation of metallic chlorides.

- The samples exposed to $\mathrm{NaCl}-\mathrm{Na}_{2} \mathrm{SO}_{4}(\mathrm{~S} 2)$ and $\mathrm{KCl}-\mathrm{K}_{2} \mathrm{SO}_{4}(\mathrm{~S} 3)$ deposits suffered less damage compared to the previous S1 deposit, although the attack was still very aggressive. The chlorides seem to trigger the active oxidation mechanism and the presence of $\mathrm{K}$ seems to accelerate it.

- The NiCr coating exposed to $\mathrm{Na}_{2} \mathrm{SO}_{4}-\mathrm{K}_{2} \mathrm{SO}_{4}-\mathrm{Fe}_{2} \mathrm{O}_{3}$ (S4) salt mixture barely suffered any damage due to the absence of chlorides and low $\mathrm{P}_{\mathrm{SO} 3}$.

- The microstructural features of the NiCr coating processed by HVOF (i.e. oxides or splat boundaries) were important when assessing their effectiveness at high temperatures. The chloride-rich salts progressed readily between the splat boundaries.

\section{Acknowledgements}

The authors wish to thank the Ministerio de Economía y Competitividad for economical support of the present research (MAT2013-48166-C3-3-R), the Comunidad de Madrid through the program ADITIMAT-CM (reference S2018/NMT-4411). The authors also wish to thank J. Piron (Vallourec Co) for supplying the steel pipes.

\section{Data availability}

The raw/processed data required to reproduce these findings cannot be shared at this time as the data also forms part of an ongoing study. 


\section{References}

[1] J. Tominaga, 3 - Steam turbine cycles and cycle design optimization: Advanced ultra-supercritical thermal power plants and nuclear power plants, Elsevier Ltd, 2017. doi:10.1016/B978-0-08-100314-5.00003-8.

[2] N.J. Simms, Environmental degradation of boiler components, Power Plant Life Manag. Perform. Improv. (2011) 145-179. doi:10.1533/9780857093806.2.145.

[3] T. Dudziak, Steam Oxidation of Fe-Based Materials, in: High Temp. Corros., 2016. doi:http://dx.doi.org/10.5772/62935.

[4] S. Lim, K.T. Lee, Leading global energy and environmental transformation: Unified ASEAN biomass-based bio-energy system incorporating the clean development mechanism, Biomass and Bioenergy. 35 (2011) 2479-2490. doi:10.1016/j.biombioe.2011.04.013.

[5] A. Di Gianfrancesco, The fossil fuel power plants technology, Elsevier, 2016. doi:10.1016/B978-0-08-100552-1.00001-4.

[6] T. Hussain, N.J. Simms, J.R. Nicholls, Modelling fireside corrosion of thermal sprayed coatings in co-firing of coal/biomass, Mater. Corros. 65 (2014) 197-205. doi:10.1002/maco.201307063.

[7] K. Natesan, a Purohit, D.L. Rink, Coal-ash Corrosion of Alloys for Combustion Power Plants, Proc. 17th Annu. Conf. Foss. Energy Mater. April 22-24, 2003. (2003) 1-15. \%5C\%5CKwiserver\%5Cliteratur\%5Cedo\%5Carticles\%5CDSH\%5CDSH_1985.pdf.

[8] R.A. Antunes, M.C.L. de Oliveira, Corrosion in biomass combustion: A materials selection analysis and its interaction with corrosion mechanisms and mitigation 
strategies, Corros. Sci. 76 (2013) 6-26. doi:10.1016/j.corsci.2013.07.013.

[9] E. Sadeghimeresht, N. Markocsan, P. Nylén, Microstructural characteristics and corrosion behavior of HVAF- and HVOF-sprayed Fe-based coatings, Surf. Coatings Technol. 318 (2017) 365-373. doi:10.1016/j.surfcoat.2016.11.088.

[10] N.F. Ak, C. Tekmen, I. Ozdemir, H.S. Soykan, E. Celik, NiCr coatings on stainless steel by HVOF technique, Surf. Coatings Technol. 173-174 (2003) 1070-1073. doi:10.1016/S0257-8972.

[11] N. Abu-warda, A.J. López, M.D. López, M.V. Utrilla, High temperature corrosion and wear behavior of HVOF-sprayed coating of Al2O3-NiAl on AISI 304 stainless steel, Surf. Coatings Technol. 359 (2018) 35-46. doi:10.1016/j.surfcoat.2018.12.047.

[12] A.J. López, M. Proy, V. Utrilla, E. Otero, J. Rams, High-temperature corrosion behavior of Ni-50Cr coating deposited by high velocity oxygen-fuel technique on low alloy ferritic steel, Mater. Des. 59 (2014) 94-102. doi:10.1016/j.matdes.2014.02.027.

[13] M.A. Uusitalo, T.A. Mantyla, High temperature corrosion of coatings and boiler steels in reducing chlorine-containing atmosphere, Surf. Coat. Technol. 161 (2002) 275-285.

[14] M.A. Uusitalo, P.M.J. Vuoristo, T.A. Mäntylä, Elevated temperature erosion corrosion of thermal sprayed coatings in chlorine containing environments, Wear. $252(2002) 586-594$.

[15] M.A. Uusitalo, P.M.J. Vuoristo, T.A. Mantyla, P.M.J. Vuoristo, T.A. Mäntylä, High temperature corrosion of coatings and boiler steels below chlorine- 
containing salt deposits, Corros. Sci. 46 (2004) 1311-1331.

doi:10.1016/j.corsci.2003.09.026.

[16] Y.S. Li, M. Spiegel, S. Shimada, Corrosion behaviour of various model alloys with NaCl-KCl coating, Mater. Chem. Phys. 93 (2005) 217-223. doi:10.1016/j.matchemphys.2005.03.015.

[17] M. Sarvghad, G. Will, T.A. Steinberg, Corrosion of steel alloys in molten $\mathrm{NaCl}+$ $\mathrm{Na} 2 \mathrm{SO} 4$ at $700{ }^{\circ} \mathrm{C}$ for thermal energy storage, Sol. Energy Mater. Sol. Cells. 179 (2018) 207-216. doi:10.1016/j.solmat.2017.11.017.

[18] A. Mlonka-Mędrala, K. Gołombek, P. Buk, E. Cieślik, W. Nowak, The influence of $\mathrm{KCl}$ on biomass ash melting behaviour and high-temperature corrosion of lowalloy steel, Energy. 188 (2019) 116062. doi:10.1016/j.energy.2019.116062.

[19] N. Abu-warda, A.J. López, M.D. López, M. V. Utrilla, Ni20Cr coating on T24 steel pipes by HVOF thermal spray for high temperature protection, Surf. Coatings Technol. 381 (2020) 125133. doi:10.1016/j.surfcoat.2019.125133.

[20] ISO/FDIS 17224:2014, Corrosion of metals and alloys — Test method for high temperature corrosion testing of metallic materials by application of a deposit of salt, ash, or other substances, 2014.

[21] T. Hussain, A.U. Syed, N.J. Simms, Trends in fireside corrosion damage to superheaters in air and oxy-firing of coal/biomass, Fuel. 113 (2013) 787-797. doi:10.1016/j.fuel.2013.04.005.

[22] A.U. Syed, N.J. Simms, J.E. Oakey, Fireside corrosion of superheaters: Effects of air and oxy-firing of coal and biomass, Fuel. 101 (2012) 62-73. doi:10.1016/j.fuel.2011.03.010. 
[23] T. Dudziak, T. Hussain, N.J. Simms, A.U. Syed, J.E. Oakey, Fireside corrosion degradation of ferritic alloys at $600^{\circ} \mathrm{C}$ in oxy-fired conditions, Corros. Sci. 79 (2014) 184-191. doi:10.1016/j.corsci.2013.11.005.

[24] M. Bai, L. Reddy, T. Hussain, Experimental and thermodynamic investigations on the chlorine-induced corrosion of HVOF thermal sprayed NiAl coatings and 304 stainless steels at $700{ }^{\circ} \mathrm{C}$, Corros. Sci. 135 (2018) 147-157. doi:10.1016/j.corsci.2018.02.047.

[25] D. Fantozzi, V. Matikainen, M. Uusitalo, H. Koivuluoto, P. Vuoristo, Chlorine induced high-temperature corrosion mechanisms in HVOF and HVAF sprayed Cr3C2-based hardmetal coatings, Corros. Sci. 160 (2019) 108166. doi:10.1016/j.corsci.2019.108166.

[26] T.M. Meißner, X. Montero, D. Fähsing, M.C. Galetz, Cr diffusion coatings on a ferritic-martensitic steel for corrosion protection in KCl-rich biomass co-firing environments, Corros. Sci. (2019) 108343. doi:10.1016/j.corsci.2019.108343.

[27] B.J. Skrifvars, R. Backman, M. Hupa, K. Salmenoja, E. Vakkilainen, Corrosion of superheater steel materials under alkali salt deposits Part 1: The effect of salt deposit composition and temperature, Corros. Sci. 50 (2008) 1274-1282. doi:10.1016/j.corsci.2008.01.010.

[28] K.A. Habib, M.S. Damra, J.J. Carpio, I. Cervera, J.J. Saura, Performance of NiCrAlY Coatings Deposited by Oxyfuel Thermal Spraying in High Temperature Chlorine Environment, J. Mater. Eng. Perform. 23 (2014) 3511-3522. doi:10.1007/s11665-014-1160-Z.

[29] A. Soleimani Dorcheh, R.N. Durham, M.C. Galetz, Corrosion behavior of stainless and low-chromium steels and IN625 in molten nitrate salts at $600{ }^{\circ} \mathrm{c}$, 
Sol. Energy Mater. Sol. Cells. 144 (2016) 109-116.

doi:10.1016/j.solmat.2015.08.011.

[30] R. Kaczmarczyk, A. Mlonka-Mędrala, Chloride corrosion in biomass-fired boilers-Fe-O-Cl system thermodynamic analysis, E3S Web Conf. 10 (2016) 0-4. doi:10.1051/e3sconf/20161000060.

[31] A. Mlonka-Mędrala, A. Magdziarz, I. Kalemba-Rec, W. Nowak, The influence of potassium-rich biomass ashes on steel corrosion above $550^{\circ} \mathrm{C}$, Energy Convers. Manag. 187 (2019) 15-28. doi:10.1016/j.enconman.2019.02.074.

[32] J. Pettersson, J.E. Svensson, L.G. Johansson, Alkali induced corrosion of 304type austenitic stainless steel at $600^{\circ} \mathrm{C}$; comparison between $\mathrm{KCl}, \mathrm{K} 2 \mathrm{CO} 3$ and $\mathrm{K}$ 2SO4, Mater. Sci. Forum. 595-598 PA (2008) 367-375. doi:10.4028/www.scientific.net/msf.595-598.367.

[33] A. Kruizenga, D. Gill, Corrosion of iron stainless steels in molten nitrate salt, Energy Procedia. 49 (2014) 878-887. doi:10.1016/j.egypro.2014.03.095.

[34] J. Pettersson, H. Asteman, J.E. Svensson, L.G. Johansson, KCl induced corrosion of a 304-type austenitic stainless steel at $600^{\circ} \mathrm{C}$; the role of potassium, Oxid. Met. 64 (2005) 23-41. doi:10.1007/s11085-005-5704-3.

[35] F.J. Pérez, M.P. Hierro, F. Pedraza, C. Gómez, M.C. Carpintero, J.A. Trilleros, Kinetic studies of $\mathrm{Cr}$ and $\mathrm{Al}$ deposition using CVD-FBR on different metallic substrates, Surf. Coatings Technol. 122 (1999) 281-289. doi:10.1016/S02578972(99)00305-9.

[36] E. Sadeghimeresht, N. Markocsan, P. Nylén, A comparative study of corrosion resistance for HVAF-sprayed Fe- and Co-based coatings, Coatings. 6 (2016) 26- 
28. doi:10.3390/coatings6020016.

[37] B.J. Skrifvars, M. Westén-Karlsson, M. Hupa, K. Salmenoja, Corrosion of superheater steel materials under alkali salt deposits. Part 2: SEM analyses of different steel materials, Corros. Sci. 52 (2010) 1011-1019. doi:10.1016/j.corsci.2009.11.026.

[38] Q.M. Wang, Y.J. Tang, M.H. Guo, P.L. Ke, J. Gong, C. Sun, L.S. Wen, Thermal shock cycling behavior of NiCoCrAlYSiB coatings on Ni-base superalloys, Mater. Sci. Eng. A. 406 (2005) 337-349. doi:10.1016/j.msea.2005.06.028.

[39] E. Sadeghimeresht, L. Reddy, T. Hussain, M. Huhtakangas, N. Markocsan, S. Joshi, Influence of $\mathrm{KCl}$ and $\mathrm{HCl}$ on high temperature corrosion of HVAFsprayed NiCrAlY and NiCrMo coatings, Mater. Des. 148 (2018) 17-29. doi:10.1016/j.matdes.2018.03.048.

[40] T. Varis, D. Bankiewicz, P. Yrjas, M. Oksa, T. Suhonen, S. Tuurna, K. Ruusuvuori, S. Holmström, High temperature corrosion of thermally sprayed $\mathrm{NiCr}$ and $\mathrm{FeCr}$ coatings covered with a $\mathrm{KCl}-\mathrm{K} 2 \mathrm{SO} 4$ salt mixture, Surf. Coatings Technol. 265 (2015) 235-243. doi:10.1016/j.surfcoat.2014.11.012.

[41] X. mei OU, Z. SUN, M. SUN, D. lian ZOU, Hot-corrosion mechanism of Ni-Cr coatings at $650^{\circ} \mathrm{C}$ under different simulated corrosion conditions, J. China Univ. Min. Technol. 18 (2008) 444-448. doi:10.1016/S1006-1266(08)60092-9.

[42] R.B. Dooley and W.P. McNaughton, Boiler Tube Failures: Theory and Practice, vol. 3, Steam Touched Tubes, EPRI, 1996.

[43] W.T. Reid, External Corrosion and Deposits: Boilers and Gas Turbines, Elsevier Science Ltd, New York, 1971. 
